\title{
Deleted in Malignant Brain Tumors-1 Protein (DMBT1): A Pattern Recognition Receptor with Multiple Binding Sites
}

\author{
Antoon J. M. Ligtenberg ${ }^{1} *$, Niclas G. Karlsson ${ }^{2}$ and Enno C. I. Veerman ${ }^{1}$ \\ 1 Periodontology and Oral Biochemistry, Academic Centre for Dentistry Amsterdam, G. Mahlerlaan \\ 3004, 1081LA, Amsterdam, The Netherlands; E-Mail: e.veerman@acta.nl \\ 2 Medical Biochemistry, University of Gothenburg, Gothenburg, Sweden Box 440, 40530 \\ Gothenburg, Sweden; E-Mail: niclas.karlsson@medkem.gu.se \\ * Author to whom correspondence should be addressed; E-Mail: a.ligtenberg@acta.nl; \\ Tel.: +31-(0)-20-5980-896.
}

Received: 11 November 2010; in revised form: 9 December 2010 / Accepted: 9 December 2010 / Published: 17 December 2010

\begin{abstract}
Deleted in Malignant Brain Tumors-1 protein (DMBT1), salivary agglutinin $\left(\mathrm{DMBT} 1^{\mathrm{SAG}}\right)$, and lung glycoprotein-340 $\left(\mathrm{DMBT} 1^{\mathrm{GP} 340}\right)$ are three names for glycoproteins encoded by the same $D M B T 1$ gene. All these proteins belong to the scavenger receptor cysteine-rich (SRCR) superfamily of proteins: a superfamily of secreted or membrane-bound proteins with SRCR domains that are highly conserved down to sponges, the most ancient metazoa. In addition to SRCR domains, all DMBT1s contain two CUB domains and one zona pellucida domain. The SRCR domains play a role in the function of DMBT1s, which is the binding of a broad range of pathogens including cariogenic streptococci, Helicobacter pylori and HIV. Mucosal defense proteins like IgA, surfactant proteins and lactoferrin also bind to DMBT1s through their SRCR domains. The binding motif on the SRCR domains comprises an 11-mer peptide in which a few amino acids are essential for binding (GRVEVLYRGSW). Adjacent to each individual SRCR domain are glycosylation domains, where the attached carbohydrate chains play a role in the binding of influenza A virus and Helicobacter pylori. The composition of the carbohydrate chains is not only donor specific, but also varies between different organs. These data demonstrate a role for DMBT1s as pattern recognition molecules containing various peptide and carbohydrate binding motifs.
\end{abstract}

Keywords: dental caries; innate immunity; mucosal protection; SRCR domains 


\section{Introduction: Saliva as a Protective Fluid}

Mucosal surfaces are the largest and most important interface between the human body and its environment, comprising a total area of approximately $300 \mathrm{~m}^{2}$ [1]. Interaction with the environment is of vital importance for the uptake of nutrients and oxygen, but the external interaction of mucosal surfaces also poses a threat the body. These threats include antigenic, mitogenic and toxic stimuli in food and in the air as well as pathogenic bacteria and viruses. To overcome these constant challenges, the immune system has developed extensive innate and adaptive responses.

The oral tissues, a part of the mucosal immune system, are constantly covered by saliva, which harbors a similar set of antimicrobial proteins as other mucosal fluids [2]. A major role of saliva is to maintain the natural oral microbial ecosystem. The function and secretion of saliva can be disturbed after radiation therapy for head and neck cancer, by auto-immune diseases affecting glandular tissues such as Sjögren's syndrome $[3,4]$ or as a side-effect of numerous drugs. A reduced saliva secretion leads to a significant increase in oral bacteria as well as to a shift in composition of the oral microflora. At the same time, the oral complications increase in number and severity [5]. Reduced saliva secretion may also affect general health. For instance, the majority of sedated patients in intensive-care units show a shift in the oral microflora from Gram-positive to Gram-negative species, which subsequently may spread into the respiratory tract causing pulmonary afflictions [6].

\section{Adherence and Oral Infections}

As a result of the continuous flow of saliva in our mouth, planktonic bacteria are swallowed, making microbial adherence one of the key selective criteria in the oral cavity $[7,8]$. Salivary proteins in solution may inhibit adherence by competition with bacterial binding sites on proteins coated at dental surfaces. Binding of salivary proteins to bacteria may result in bacterial agglutination which is, therefore, considered as a mechanism for clearance of bacteria and protection against dental caries [9-11]. One of the important bacteria agglutinating proteins is Deleted in Malignant Brain Tumors-1 protein (DMBT1) also known as Salivary Agglutinin (DMBT1 ${ }^{\mathrm{SAG}}$ ) $[12,13]$.

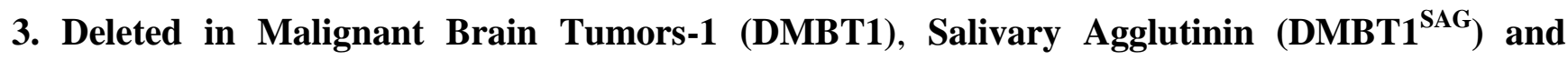 Glycoprotein 340 (DMBT1 ${ }^{\text {GP340 }}$ )}

Streptococcus mutans is considered the major cause for dental caries. In search for $S$. mutans agglutinating substances, Ericson and Rundegren isolated a 300-400 kDa glycoprotein from parotid saliva [12] that showed calcium-dependent binding to $S$. mutans. This protein was named salivary agglutinin $\left(\mathrm{DMBT}^{\mathrm{SAG}}\right.$ ). It also binds a number of both Gram-positive and Gram-negative bacteria, as well as to host proteins including $\operatorname{IgA}$, complement factor $\mathrm{C} 1 \mathrm{q}$, bovine and human lactoferrin, albumin and lysozyme [14-19]. Several studies have shown that the protein core of DMBT1 ${ }^{\mathrm{SAG}}$ is identical with lung glycoprotein 340 (DMBT1 ${ }^{\mathrm{GP} 340}$ ) and Deleted in Malignant Brain Tumors-1 (DMBT1) [20-22]. The amino acid sequences characterized so far are identical to the one deduced from the DMBT1 gene $[23,24]$. DMBT1 ${ }^{\text {SAG }}$ and DMBT1 $1^{\text {gp-340 }}$ cross react with monoclonal antibodies raised against the DMBT1s isolated from the different sources. Both proteins show calcium-dependent binding to S. mutans and SP-D [21]. DMBT1 ${ }^{\mathrm{GP} 340}$ was purified from bronchoalveolar lavage fluid of 
patients with alveolar proteinosis [20]. It binds to surfactant proteins A (SP-A) and D (SP-D) [25], members of the collectin family that play an important role in innate immunity by binding to specific carbohydrate structures on the surface of pathogenic micro-organisms [26]. DMBT1 ${ }^{\mathrm{SAG}}$ and DMBT $1^{\text {GP340 }}$ thus represent DMBT1 isoforms that are encoded by the DMBT1 gene on chromosome 10q26.13. The DMBT1 gene shows frequent genomic rearrangements and/or loss of expression in two common types of malignant brain tumors, but also in diverse epithelial cancer types, including lung, gastric, esophageal, colon, breast, and skin cancer [27-36]. A search through the human genome revealed only one copy of the gene. Genetic polymorphism results in variants with different numbers of SRCR exons. In addition, different isoforms may arise through alternative splicing or differential post-translational modifications such as glycosylation.

\section{The Domain Organization of DMBT1}

The most typical feature of DMBT1 is that it consists of protein domains (Figure 1). DMBT1 is a member of the scavenger receptor cysteine-rich (SRCR) superfamily, which is characterized by the presence of one or more SRCR domains [23,24]. In between each of the multiple SRCR domains, all located to the $\mathrm{N}$-terminal end of the DMBT1s, are short serine-threonine-rich amino acid motifs of 20-24 amino acids in length, called SRCR interspersed domains (SIDs). The largest naturally occurring allele known to date contains 13 of these SRCR-SID units, while the shortest known displays only eight. This genetic variability in normal individuals raises the question if size variations of DMBT1 $1^{\mathrm{GP} 340}, \mathrm{DMBT} 1^{\text {SAG }}$ and variants from other tissues are due to alternative splicing and post-translational processing or are alternatively determined by genetic differences.

The stretch of tandem repeated SRCR domains with their interspersed SIDs are followed by two CUB domains separated by a 14th SRCR domain, and at the $C$-terminal end of the gene is a Zona Pellucida domain. Except for the SIDs, these domains are all known to be involved in ligand binding [37-39]. DMBT1 orthologs have been identified in various mammalian organisms such as mouse (dmbt1, CRP-ductin, vomeroglandin, muclin, apactin), rat (dmbt1, ebnerin, pancrin), rabbit (hensin), cow (bovine gall bladder mucin), pig (dmbt1) and rhesus monkey (H3) (Table 1). These proteins all have in common that they consist of SRCR, CUB and ZP domains although the number and order of these domains may be different (Figure 1).

Table 1. DMBT1 synonyms and orthologs in different organisms.

\begin{tabular}{lll}
\hline Organism & Name & Function \\
\hline Human & DMBT1 & Tumor suppression \\
& gp-340 & Epithelial cell differentiation \\
& SAG & Innate immunity \\
\hline Mouse & CRP-ductin & Mucosal defense \\
& Vomeroglandin & Epithelial differentiation \\
& Muclin & Pheromone perception \\
& apactin & Sorting receptor \\
\hline Rabbit & Hensin & Terminal differentiation of kidney epithelial \\
& & intercalated cells and embryonic stem cells \\
\hline Rat & Ebnerin & Liver regeneration \\
& Pancrin & Taste perception \\
\hline
\end{tabular}


Table 1. Cont.

\begin{tabular}{|c|c|c|}
\hline Organism & Name & Function \\
\hline Pig & Porcine dmbt1 & \\
\hline Cow & $\begin{array}{l}\text { Bovine gallbladder } \\
\text { mucin }\end{array}$ & $\begin{array}{l}\text { Cholesterol-binding } \\
\text { Gallstone formation }\end{array}$ \\
\hline Rhesus monkey & H3 & $\begin{array}{l}\text { Hormone-responsive } \\
\text { Endometrial regeneration in ovulation cycle }\end{array}$ \\
\hline
\end{tabular}

Figure 1. Domain organization of DMBT1 and DMBT1 orthologs. This picture was adapted from J.Mollenhauer [35]. DMBT1/8 kb.2 and DMBT1/6 kb.1 represent the largest and the smallest human variant, respectively, that have been recovered so far. The DMBT1 prototype features 13 scavenger receptor cysteine rich (SRCR) domains, separated by SIDs. The SRCR domains are followed by a short Thr-rich region, a CUB domain, a 14th SRCR domain, a Ser-Thr-Pro-rich region, a second CUB domain, and a Zona Pellucida domain. The DMBT1 orthologs from the rabbit (Hensin), Mouse (CRP-ductin-alfa), rat (Ebnerin) and pig have varying numbers of SRCR domains, followed by one or more CUB domains, and share a $C$-terminal SRCR domain, CUB domains and Zona Pellucida domain.

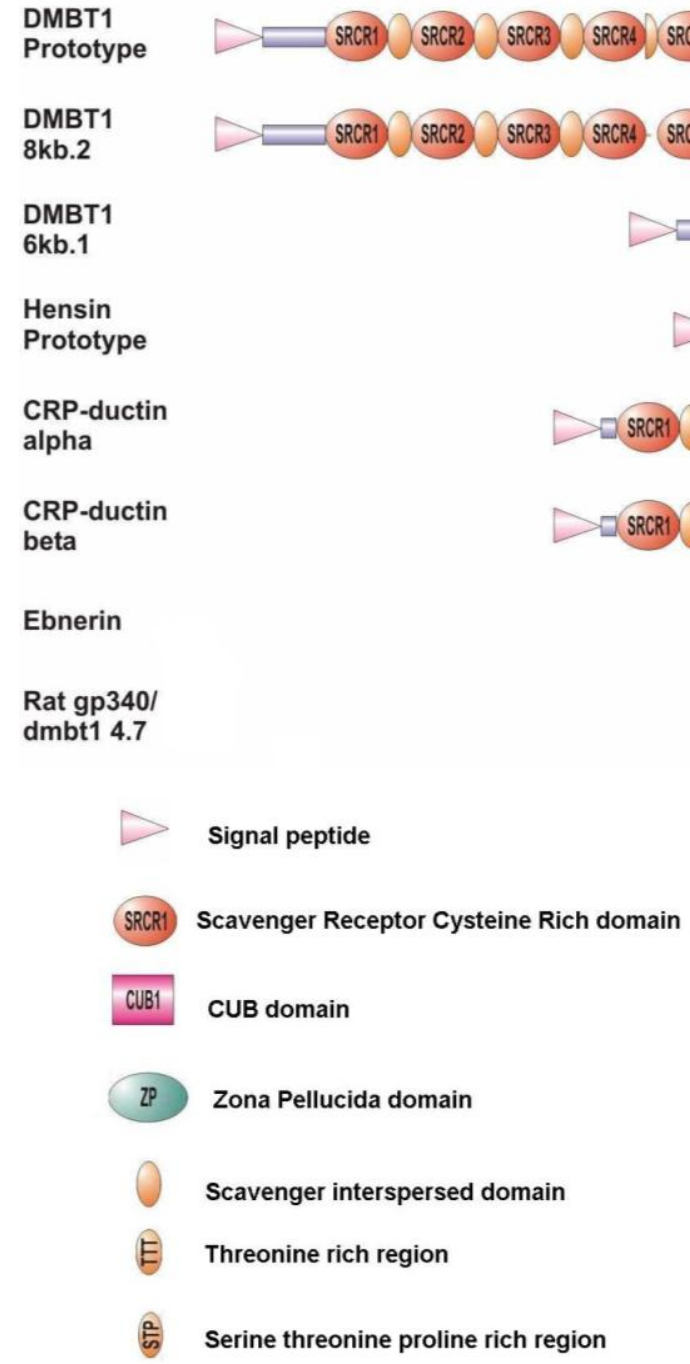




\section{SRCR Domains}

The most prevalent domains in DMBT1 are the SRCR domains [38]. The SRCR superfamily consists of both membrane bound and secreted proteins which play a role in ligand binding [40]. SRCR proteins are present in multicellular animals along the entire animal kingdom, with their earliest appearance in sponges $[38,41,42]$. In addition, they also appear in protozoan parasites such as Cryptosporidium, Toxoplasma and Plasmodium and algae of the genus Chlamidomonas [43,44]. The organism with the highest number of SRCR domains is the purple sea urchin, Strongylocentrotus purpuratus, which contains 218 genes comprising altogether 1,095 SRCR domains [45]. For these SRCR proteins, a role as innate immune receptors was suggested since this organism also has a high number of innate immune receptors such as Toll-like receptors. Despite their presence in a large variety of animals [42], SRCR domains have retained a high degree of conservation. SRCR domains are 100-110 amino acids long and can be subdivided into two groups: members of group A contain SRCR domains with six cysteine residues, which are encoded by two exons; members of group B, to which DMBT1 belongs, usually contain SRCR domains with eight cysteine residues and are encoded by a single exon [38]. The position of the cysteines and their disulfide bond pattern are well conserved within each SRCR domain. The disulfide bond pattern of a group B SRCR domain is C1-C4, C2-C7, C3-C8 and C5-C6 [42].

\section{CUB Domains}

The CUB domain is a 100-110 residue-spanning extracellular domain named after the three proteins, in which it was first recognized: Complement subcomponents (ㄷ1s/C1r), embryonic sea urchin protein (Uegf; sea urchin epidermal growth factor), and bone morphogenetic protein 1 (ㅡmp1). CUB domains are found in numerous proteins that are mainly involved in developmental processes [39]. Almost all CUB domains contain four conserved cysteines, which probably form two disulfide bridges $(\mathrm{C} 1-\mathrm{C} 2, \mathrm{C} 3-\mathrm{C} 4)$. The structure of the CUB domain has been predicted to be a beta-barrel similar to that of immunoglobulins [46].

\section{Zona Pellucida Domains}

The zona pellucida (ZP) domain was first recognized in the sperm receptor proteins ZP2 and $\mathrm{ZP} 3$ [39,47]. These proteins are, along with ZP1, responsible for sperm adhesion to the zona pellucida, the glycoprotein membrane surrounding the plasma membrane of the oocyte. The ZP domain is a $\sim 260$ amino acid module which contains eight conserved cysteines, forming four disulfide bridges. The disulfide bonding pattern suggests that the ZP domain consists of two subdomains. In addition to the conserved cysteines, a few aromatic or hydrophobic amino acids are absolutely invariant [48]. ZP domains are usually present in glycosylated proteins containing other domains and usually located at the $C$-terminal of the polypeptide, which is also the case for DMBT1s. The functions of proteins containing a ZP domain vary tremendously. They are found in glycoproteins involved in development, acoustic perception, immunity, and cancer [49]. ZP domains have been suggested to play a role in protein oligomerization [50]. This is consistent with the model that DMBT1 ${ }^{\mathrm{SAG}}$ forms aggregates [51,52]. 


\section{Glycosylation Patterns of DMBT1 ${ }^{\text {SAG }}$}

The carbohydrate part of DMBT1 ${ }^{\text {SAG }}$ accounts for $25-40 \%$ of the molecular weight [23,52]. DMBT1s contains up to 14 potential $N$-linked glycosylation sites [23], and numerous potential $O$-linked sites situated primarily in the SIDs. The SRCR domains, however, contain only few potential $O$-glycosylation sites (Ser and Thr residues). Presumably, the high density of glycans forces the SIDs in an extended conformation, as has been demonstrated for mucins [53], thereby creating a molecule with alternating stretched SIDs and globular SRCR domains.

The dominating $O$-linked structures in DMBT1 ${ }^{\mathrm{SAG}}$ are extended core 1 and core 2 oligosaccharides, either neutral or monosialylated (Table 2). These structures are extended by fucosylated oligo- $N$-acetyllactosamine units. Sialylation and fucosylation are found terminating the $N$-acetyllactosamine chains as Sialyl-Le ${ }^{\mathrm{x}}$ or $\mathrm{Le}^{\mathrm{b}} / \mathrm{Le}^{\mathrm{y}}$, respectively. Sialylated structures tend to be shorter than fucosylated structures, suggesting that sialylation regulates the $\mathrm{N}$-acetyllactosamine extension.

Glycosylation of proteins is controlled by genetically encoded glycosyltransferases [54]. The Se gene, which determines the presence of blood group antigens in secretory fluids, encodes a $\alpha 1,2$-fucosyltransferase. This enzyme couples a fucose to galactose (Fuc 1 1-2Gal), which is the first step in the generation of blood group antigens. Consequently, non-secretors have a different carbohydrate composition compared to secretors. Non-secretors have $\mathrm{Le}^{\mathrm{a}}$ and $\mathrm{Le}^{\mathrm{x}}$ structures on $\mathrm{DMBT}^{\mathrm{SAG}}$; secretors also have $\mathrm{Le}^{\mathrm{b}}$ and $\mathrm{Le}^{\mathrm{y}}$ and $\mathrm{ABH}$ structures, in addition to $\mathrm{Le}^{\mathrm{a}}$ and $\mathrm{Le}^{\mathrm{x}}$ on $\mathrm{DMBT}^{\mathrm{SAG}}[13,55]$. DMBT1 ${ }^{\mathrm{SAG}}$ from secretors has a higher molecular mass than DMBT1 ${ }^{\mathrm{SAG}}$ from non-secretors [55]. Although evidence has been obtained that blood group antigens such as $\mathrm{ABH}$ and the $\mathrm{Le}^{\mathrm{a}}$ antigens function as ligands for bacterial receptors, and thus might be involved in bacterial binding [56-58], only a few papers describe a correlation between blood group status and the susceptibility to caries [59].

Glycosylation of lung DMBT1 $1^{\mathrm{GP} 340}$ is different from that of salivary DMBT1 ${ }^{\mathrm{SAG}}$. Lung DMBT $1^{\text {GP340 }}$ completely lacks ABH and Le antigens [55] and its content of $\alpha 2,3$ linked sialic acid residues seems to be lower than that of salivary $\mathrm{DMBT} 1^{\mathrm{SAG}}$ [60]. It is not clear, however, to what extent this difference is related to individual variation in glycosylation, as the preparations were from different donors. Differences are also found for tear DMBT1 when compared to saliva DMBT1 ${ }^{\mathrm{SAG}}$. In contrast to saliva, DMBT1 in tears had no sialyl-Le ${ }^{\mathrm{x}}$. [61].

Also, time-dependent variations in glycosylation patterns have been reported. The reactivity of $\mathrm{DMBT}^{\text {SAG }}$ with antibody MECA-79, which recognizes the L-selectin ligand $\mathrm{SO}_{3}-6 \mathrm{GlcNAc}[62,63]$, fluctuates during the ovulation cycle. It is low shortly after menstruation and reaches a maximum a few days after ovulation. Also, during pregnancy and lactation, reactivity is high. These results suggest that sulfation of DMBT1 $1^{\text {SAG }}$ is hormonally regulated [63]. 
Table 2. Overview of glycan chains found on $D M B T 1$.

\begin{tabular}{|c|c|c|c|c|}
\hline Oligosaccharide & Structure & Method & Source & Reference: \\
\hline $\begin{array}{l}\text { core } 1 \\
\text { sialylated-core } 1 \\
\text { disialylated-core } 1 \\
\text { core } 2 \\
\text { sialylated-core } 2 \\
\end{array}$ & $\begin{array}{l}\text { Gal } \beta 1-3 \text { GalNAc } \alpha 1-S e r / T h r \\
\text { NeuAc } \alpha 2-3 \text { Gal } \beta 1-3 \text { GalNAc } \alpha 1-S e r / T h r \\
\text { NeuAc } \alpha 2-3 \text { Gal } \beta 1-3(\text { NeuAc } \alpha 2-6) \text { GalNAc } \alpha 1-S e r / T h r \\
\text { Gal } \beta 1-3(G l c N A c \beta 1-6) \text { GalNAc } \alpha 1-S e r / T h r \\
\text { NeuAc } \alpha 2-3 \text { Gal } \beta 1-3(\text { GlcNAc } \beta 1-6) \text { GalNAc } \alpha 1-S e r / T h r\end{array}$ & $\begin{array}{l}\mathrm{LC}^{-M S^{2}} \\
\mathrm{LC}^{2} \mathrm{MS}^{2}\end{array}$ & Tears/Saliva & {$[61,64]$} \\
\hline $\begin{array}{l}(\text { Le-a }) \\
(\text { Le-x }) \\
(\text { Le-b) } \\
(\text { Le-y) } \\
\text { H antigen } \\
\text { A antigen } \\
\text { B antigen } \\
(\text { Sialyl-Le } \\
\text { Sialyl-Le }^{\mathrm{a}}\end{array}$ & $\begin{array}{l}\text { Gal } \beta 1-4(\text { Fuc } \alpha 1-3) \text { GlcNAc } \\
\text { Gal } \beta 1-3(\text { Fuc } \alpha 1-4) \text { GlcNAc } \\
\text { Fuc } \alpha 1-2 \text { Gal } \beta 1-4(\text { Fuc } \alpha 1-3) \text { GlcNAc } \\
\text { Fuc } \alpha 1-2 \text { Gal } \beta 1-3(\text { Fuc } \alpha 1-4) \text { GlcNAc } \\
\text { Fuc } \alpha 1-2 \text { Gal } \beta 1-4 G l c N A c \\
\text { GalNAc } \alpha 1-3(\text { Fuc } \alpha 1-2) \text { Gal } \beta 1-4 G l c N A c \\
\text { Gal } \alpha 1-3(\text { Fuc } \alpha 1-2) \text { Gal } \beta 1-4 G l c N A c \\
\text { NeuA- } \alpha 2-3 \text { Gal } \beta 1-3(\text { Fuc } \alpha 1-4) \text { GlcNAc } \\
\text { NeuAc } \alpha 2-3 \text { Gal } \beta 1-4(\text { Fuc } \alpha 1-3) \text { GlcNAc } \\
\text { NeuAc } \alpha 2-3 \\
\text { NeuAc } \alpha 2-6_{\mathrm{SO}_{3}-6 G l c N A c}\end{array}$ & $\begin{array}{l}\text { immunoblotting } \\
\text { immunoblotting } \\
\text { immunoblotting/LC-MS } \\
\text { immunoblotting/LC-MS } \\
\text { immunoblotting/LC-MS } \\
\text { immunoblotting } \\
\text { immunoblotting } \\
\text { immunoblotting } \\
\text { Immunoblotting/LC-MS } \\
\text { lectin blotting } \\
\text { lectin blotting } \\
\text { Immunoblotting }\end{array}$ & $\begin{array}{l}\text { Saliva } \\
\text { Saliva } \\
\text { Saliva } \\
\text { Saliva } \\
\text { Saliva } \\
\text { Saliva } \\
\text { Saliva } \\
\text { saliva, not lung } \\
\text { Tears } \\
\text { Saliva, not lung } \\
\text { lung, saliva } \\
\text { Saliva }\end{array}$ & $\begin{array}{l}{[13]} \\
{[13,22]} \\
{[13,64]} \\
{[13,64]} \\
{[13,64]} \\
{[13]} \\
{[13]} \\
{[22]} \\
[61]] \\
{[60]} \\
{[60]} \\
{[63]}\end{array}$ \\
\hline
\end{tabular}




\section{Bacteria Binding Sites on DMBT1 ${ }^{\text {SAG }}$}

\subsection{Binding Sites on the SRCR Domains}

For DMBT1 ${ }^{\text {SAG }}$, the SRCR domains are identified as bacteria-binding sites. Proteolytic cleavage of DMBT1 ${ }^{\text {SAG }}$ with Lys-C results in a protein fragment of 1722 amino acids, only containing SRCR domains and SIDs, which still binds to S. mutans [65]. The SRCR domains in this protein fragment show a high degree of homology, which justifies the design of a consensus sequence. Based on this consensus sequence, synthetic peptides were designed consisting of the fragments between the cysteine residues covering the full SRCR domain and SID fragments. Bacterial binding was restricted to a 16-mer peptide (QGRVEVLYRGSWGTVC) representing the second fragment in the SRCR domain and therefore named SRCRP2 [65]. This peptide binds S. mutans and a number of other bacterial species including Streptococcus gordonii, Staphylococcus aureus, Escherichia coli and H. pylori [66]. Bacterial adhesion to the peptide correlates with adhesion to the full molecule (Figure 2) [67].

Figure 2. Correlation between bacteria binding to DMBT1 ${ }^{\mathrm{SAG}}$ and SRCRP2 [67].

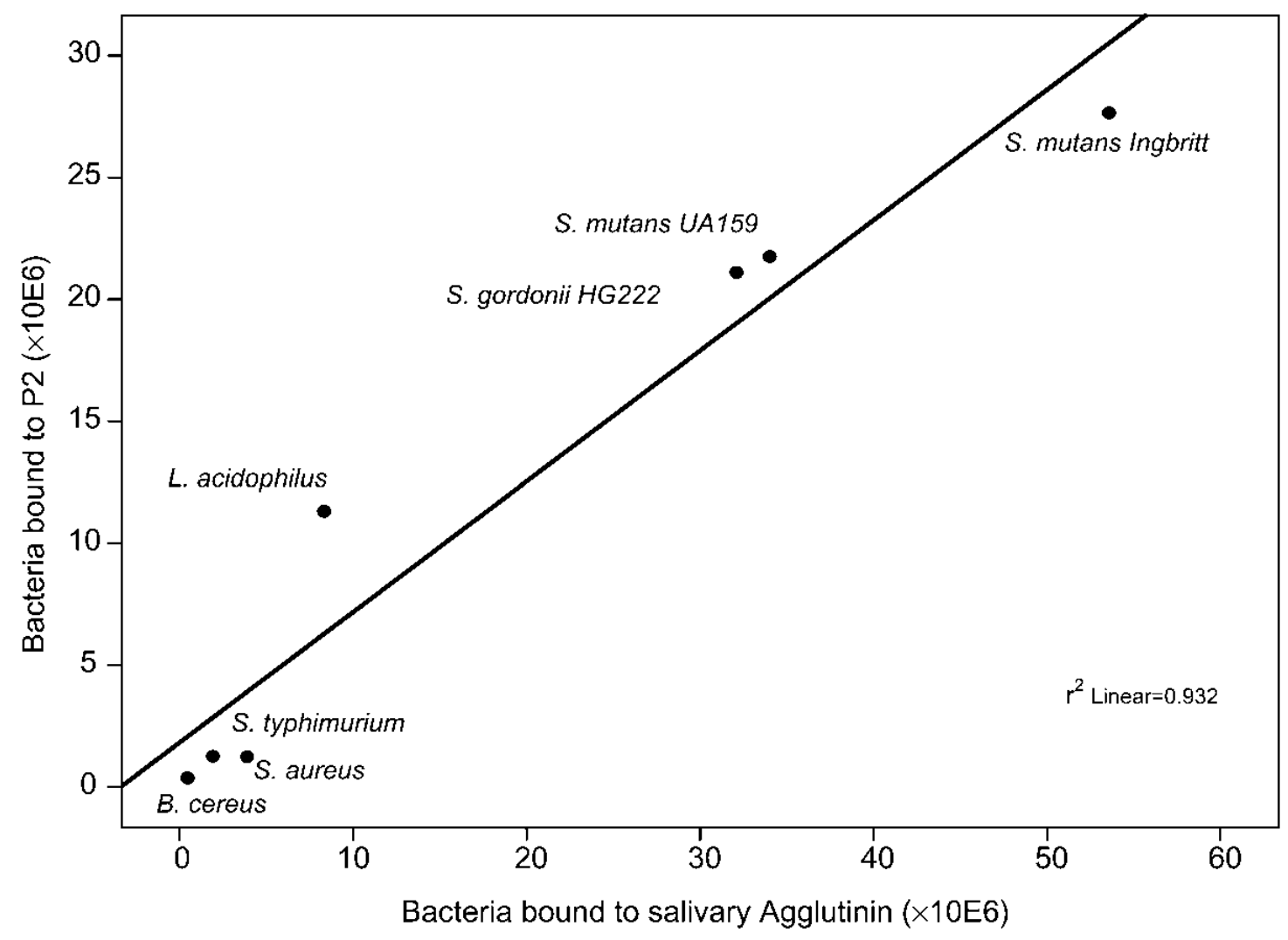

$N$ - and $C$-terminal truncation resulted in an 11-mer peptide still able to bind bacteria, therefore named DMBT1 pathogen binding site 1 (DMBT1pbs1) [66]. Although bacterial binding within the SRCR domains is only restricted to the 11-mer peptide, within the peptide different residues are essential for binding of different bacteria. Alanine scanning analysis demonstrated that eight residues out of 11 were involved in binding of different bacterial species (GRVEVLYRGSW). Of these eight residues, four were always present in the binding motif (GR트는 RGS $\underline{W}$ ). Of the 14 SRCR domains in the full length molecule, 12 contain the eight amino acids involved in binding giving 
bacterial binding of DMBT1 a multivalent character. One of the two deviating SRCR domains is the 14th SRCR domain (GRVEIYHGGTW), located between two CUB domains and as such probably not involved in bacterial binding.

SRCR domains in other proteins have previously been implicated in bacteria binding [68-70]. The bacteria binding site locates in a similar region of the group A SRCR domains in MARCO, which is a macrophage receptor recognizing bacterial surface components such as LPS and LTA. In this case, an RXR-motif, adjacent to the SRCRP2 peptide motif, is responsible for bacterial interactions (GSSNRGRAEVYYSG) [71,72]. Similarly, the bacteria binding sites in human Spa and CD6, both group B members of the SRCR superfamily that are expressed by lymphoid macrophages and lymphocytes, are also located in the SRCR domain. [73,74]. CD 163 (M130), a macrophage receptor only consisting of nine SRCR domains, also binds bacteria. Peptides homologous to the DMBT1 ${ }^{\text {SAG }}$ bacteria binding site were synthesized for all nine SRCR domains and tested for bacteria binding [75]. One of these nine peptides, of SRCR domain 3, showed good binding to bacteria (GRIEIKFQGRW).

\subsection{Binding Sites on the Glycan Chains}

Studies of bacterial binding sites on SAG were first mainly focused on carbohydrate ligands, following the concept that bacteria primarily recognize carbohydrate ligands on mucosal

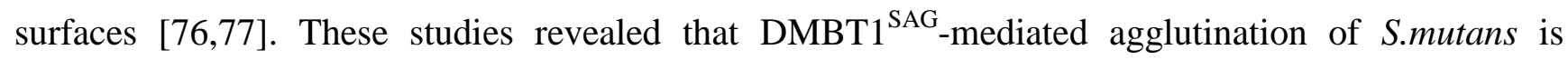
inhibited by high concentrations of fucose and lactose. In line with these results, it was shown that the Le $\mathrm{a}^{\mathrm{a}}$-antigen (Gal $\beta 1,3(\mathrm{Fuc} \alpha 1,4)$ GlcNAc) was involved in S.mutans binding, harboring an essential role for the terminal fucose [13]. Other studies demonstrated that sialic acid plays a role in binding of $\mathrm{DMBT}^{\mathrm{SAG}}$ to $S$. sanguis and $S$. mutans $[52,78]$. H. pylori can bind $\mathrm{Le}^{\mathrm{b}}$ structures and sialic acid on DMBT1 ${ }^{\text {SAG }}$ with its BabA and SabA adhesins, respectively [64].

\section{DMBT1 ${ }^{\text {SAG }}$ Binding Sites on Bacteria}

\subsection{Antigen I/II Polypeptides}

$\mathrm{DMBT}^{\mathrm{SAG}}$ was first described as an agglutinating agent for S.mutans and other streptococci [12]. Several studies have underlined the importance of bacterial agglutination in the protection against dental caries [9,79-81]. High concentrations of DMBT1 ${ }^{\text {SAG }}$ on the dental surface promoted S. mutans colonization, but high concentrations in saliva inhibit its colonization [80].

DMBT1 ${ }^{\text {SAG }}$ binds in a calcium-dependent manner to antigen I/II polypeptides, a group of surface receptors on $S$. mutans and related streptococci. Antigen I/II polypeptides have been characterized under different names in a variety of streptococci, S. mutans (antigen B, P1, Pac, SpaP, MSL-1), S. sobrinus (PAg, SpaA), S. gordonii (SspA, SspB), S. intermedius (Pas), S. pyogenes (aspA) and S. agalactiae (bspD) [82,83]. Antigen I/II polypeptides on oral streptococci have been studied extensively as candidates for vaccine development [84]. These polypeptides, between 826 and 1653 amino acids long, share a common primary sequence (Figure 3). All proteins start with a 38 amino acid (aa) leader sequence that is cleaved off during secretion. The A-region, containing one to four copies of an 82 aa residues alanine-rich sequence, is found 165 aa residues downstream of this leader. This is followed by a variable region (V-region) and then by a proline-rich P-region containing 
one to three copies of a 39 residue sequence block. The $C$-terminal region of about 615 amino acids shows $64 \%$ or more sequence homology between the I/II polypeptides.

Figure 3. Schematic overview of the structural organization of antigen I/II polypeptides. All proteins contain a 38 residues leader peptide. 165 amino acid residues downstream of the leader peptide is the alanine-rich region containing 1-4 repeats of an 82 residues alanine-rich repeat. This is followed by a variable $(\mathrm{V})$ region, followed by proline-rich $\mathrm{P}$ region containing $1-3$ copies of a 39 residues repeat. The $C$-terminus shows $\geq 64 \%$ homology along the antigen I/II protein family. $C$-terminally is the cell wall anchoring sequence (CWA).

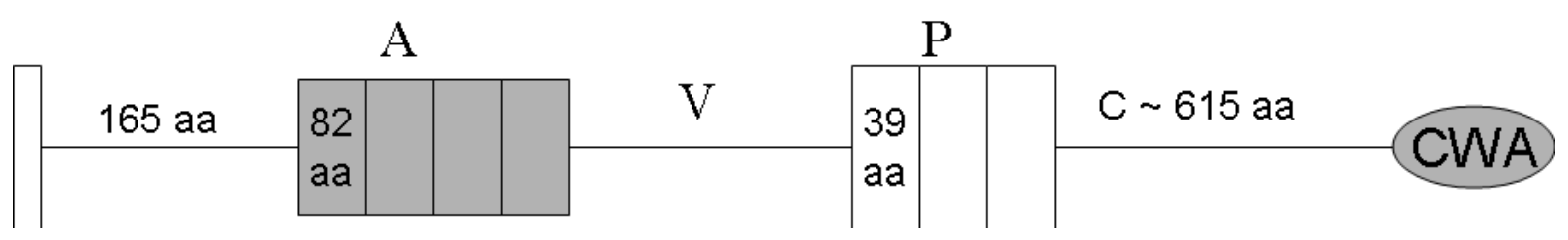

Table 3. Binding sites for $\mathrm{DMBT} 1^{\mathrm{SAG}}$ on various proteins.

\begin{tabular}{llcc}
\hline Protein & Sequence & SRCRP2 binding & Ref. \\
\hline S.mutans antigen I/II & PQLKTADLPAGRDETTSFVLV & {$[85]$} \\
\hline $\begin{array}{l}\text { S.gordonii } \text { antigen I/II } \\
\text { S.mutans } \text { antigen I/II }\end{array}$ & ELKTEALTAGRPKTTSFVLV & & {$[86]$} \\
\hline $\begin{array}{l}\text { S.gordonii SspB 390-402 } \\
\text { S.gordonii SspB 390- }\end{array}$ & DYQAKLAAYQTEL DYQAKLAAYQKEL & + & {$[87]$} \\
T400K-402 & & + & \\
\hline SsP(A4K-A11K) & DYQKKLAAYQKEL & + & {$[88]$} \\
Consensus SspA and B & DYQAKLAAYQAEL & + & \\
\hline Bovine lactoferrin 480-492 & SCAFDEFFSQSCA & + & {$[89,90]$} \\
\hline Human lactoferrin & DCKFDEYFSQSCA & {$[91]$} \\
\hline Human casein & LLNQELLNPTHQIYPVTQPLAPVHNPISV & {$[91]$} \\
\hline HIV V3 region & CTRPNYNKRKR & {$[92]$} \\
\hline
\end{tabular}

A number of putative binding sites for DMBT1 ${ }^{\mathrm{SAG}}$ were identified on antigen I/II polypeptides and other proteins (Table 3). Insight has come from the elucidation of the tertiary structure of antigen I/II [83,93]. The V-region of $\mathrm{Ag}$ I/II polypeptides may adopt a lectin-like conformation, supporting the suggestion that antigen I/II polypeptides bind to DMBT1 ${ }^{\text {SAG }}$ by recognition of carbohydrate moieties [94]. This V-region is projected from the cell surface by a stalk formed by an association between an $N$-terminal $\alpha$-helix of the alanine-rich repeats and a $C$-terminal polyproline helix. The $C$-terminus of antigen I/II, which is in close vicinity to the cell surface, also binds $\mathrm{DMBT}^{\text {SAG }}[85,93]$. A synthetic 20-mer peptide, corresponding to residues 1025-1044 of antigen I/II (PQLKTADLPAGRDETTSFVLV), inhibited binding to DMBT1 ${ }^{\text {SAG }}$ and selectively inhibited colonization of S.mutans to the tooth surface [85]. The presence of two binding sites for DMBT1 ${ }^{\text {SAG }}$ may also explain the intriguing observation that streptococcal binding to surface immobilized $\mathrm{DMBT}^{\mathrm{SAG}}$ is different from binding to DMBT1 ${ }^{\mathrm{SAG}}$ in solution [95,96]. Overlapping, but not identical, subsets of monoclonal antibodies against antigen P1 inhibited SAG mediated adherence and 
aggregation, indicating that in the adsorbed state, other domains were involved in the interaction with bacteria than in the soluble phase. Furthermore, DMBT1 ${ }^{\mathrm{SAG}}$ in solution and adsorbed DMBT1 ${ }^{\text {SAG }}$ were differentially recognized by streptococci, which formed three phenotypic groupings according to their modes of interaction: one group binding to both surface-bound and soluble DMBT1 ${ }^{\mathrm{SAG}}$, one group binding only to surface-bound $\mathrm{SAG}$, and one group interacting preferentially with soluble DMBT $1^{\text {SAG }}$ [95]. Deletion of antigen I/II polypeptides in $S$. gordonii reduced adhesion to immobilized DMBT $1^{\mathrm{SAG}}$ by $40 \%$, while deletion of Hsa - another streptococcal surface antigen - reduced adhesion by $80 \%$. In contrast, aggregation by DMBT1 ${ }^{\mathrm{SAG}}$ disappeared after deletion of antigen I/II polypeptides but was not affected by deletion of Hsa [97]. The differences in binding between absorbed and soluble state is not unique to DMBT1 ${ }^{\mathrm{SAG}}$, and has been reported for the protein-bacterial interaction between Actinomyces viscosus and acidic proline rich proteins as well as statherin. A. viscosus only bound to surfaces coated with these proteins, but not to the same proteins in solution. [98,99]. This is attributed to a conformational change which takes place when the proteins are adsorbed onto a surface, resulting in the exposure of previously hidden bacterial receptors, cryptitopes. Statherin is a peptide which in solution has no defined tertiary structure. Upon adsorption onto a hydroxyapatite surface, the $C$-terminal region folds into a $\alpha$-helical conformation, which is recognized by bacterial receptors [100]. Conclusive evidence for differences in soluble and surface bound DMBT1 ${ }^{\mathrm{SAG}}$ remains to be demonstrated by identifying the epitopes that are exposed only on immobilized DMBT1 ${ }^{\text {SAG }}$ compared to soluble DMBT1 ${ }^{\mathrm{SAG}}$, and vice versa.

\subsection{Pathogen Associated Molecular Patterns}

Bacteria that do not possess antigen I/II polypeptides, like H. pylori and Staphylococcus aureus, also bind DMBT1 ${ }^{\mathrm{SAG}}[22,65]$. CRP-ductin, the mouse homolog of DMBT1, bind to several $\mathrm{Gram}^{+}$and Gram $^{-}$bacteria, including Haemophilus influenzae, Klebsiella oxytoca, S. aureus and Streptococcus pneumoniae [101]. As many SRCR proteins are pattern recognition receptors, DMBT1 ${ }^{\mathrm{SAG}}$ might also recognize common motifs on pathogens, so-called PAMPs (pathogen associated molecular patterns). DMBT $1^{\text {SAG }}$ binds to lipoteichoic acid, a component on the membrane of Gram-positive bacteria, and to lipopolysaccharide (LPS), a common component on the cell membrane of Gram-negative bacteria. LPS has been found to bind to SRCRP2, suggesting DMBT1 recognizes LPS with its SRCR domains [102]. Binding studies to truncated variants of LPS from Salmonella showed that binding depended on the availability and accessibility of phosphorylated structures on LPS. In addition, sulfated substances such as dextran sodium sulfate (DSS) and the food stabilizer carrageenan also bound to DMBT1. DSS is used to induce colitis in mice in a disease model for ulcerative colitis. In a DSS-induced colitis model, Dmbt $1^{-/-}$mice were more susceptible to low doses of DSS than $D m b t 1^{+/+}$mice. However, since this is a commensal bacteria induced colitis model, this effect is likely to be attributed to Dmbtl's ability to control the natural intestinal microflora.

\section{Interaction with Viruses}

Besides bacteria, DMBT1 ${ }^{\text {SAG }}$ also binds viruses, including HIV-1 [92,103] and influenza A virus [60,104]. HIV-1 infects host cells by binding to the CD4 receptor through the viral envelope glycoprotein gp120, which leads to conformational changes in gp120 allowing high affinity interaction with chemokine receptors $[105,106]$. DMBT1 ${ }^{\text {SAG }}$ shows a calcium-dependent interaction with the 
virus gp120. The DMBT1 ${ }^{\mathrm{SAG}}$ binding region on gp120 is localized to a linear, highly conserved sequence (CTRPNYNKRKR) near the stem of the V3 loop that is critical for chemokine receptor interaction during viral binding and infection [92]. Thus, DMBT1 ${ }^{\mathrm{SAG}}$ most probably blocks the access of gp120 to the chemokine receptor. The $N$-terminal sequence of DMBT1, including the first SRCR domain and one-half of the first SID, binds in a $\mathrm{Ca}^{2+}$-dependent manner to the same HIV-1 V3 sequences previously identified to interact with full-length SAG [107].

$\mathrm{DMBT}^{\text {SAG }}$ and DMBT1 ${ }^{\text {GP340 }}$ also inhibit the hemagglutination activity and infectivity of Influenza A virus (IAV) [104], which is responsible for outbreaks of influenza. IAV infects cells of the respiratory tract by binding to sialic acid residues present at the cell surface. Different influenza strains recognize specifically $\alpha(2,3)$-linked or $\alpha(2,6)$-linked sialic acid. DMBT1 has broad antiviral activity against human, equine and porcine IAV strains by sialic acid mediated binding to IAV, which results in virus neutralization [60]. A variant of $\mathrm{DMBT} 1^{\mathrm{SAG}}$ had significantly greater inhibitory activity against avian-like IAV strains which preferentially bound sialic acids in $\alpha(2,3)$ linkage, than $\mathrm{DMBT} 1^{\mathrm{SAG}}$ from another donor or three lung preparations of DMBT1 ${ }^{\text {GP340 }}$ [60]. In line with this, a greater density of $\alpha(2,3)$-linked sialic acids was present on the DMBT1 ${ }^{\text {SAG }}$ from this donor as compared with the other samples. Hence, the specificity of sialic acid linkages on DMBT1 is an important determinant of anti-IAV activity. In addition to these direct virus-neutralizing properties, DMBT $1^{\text {GP340 }}$ displays cooperative interactions with SP-D in viral neutralization and aggregation assays. On the other hand, in some cases DMBT1 ${ }^{\text {SAG }}$ strongly antagonizes the antiviral activities of SP-D by binding to its carbohydrate recognition domain, which is involved in virus binding [60].

\section{Interaction with Endogenous Protein Ligands}

DMBT1 binds to a number of endogenous proteins such as secretory IgA, MUC5B, surfactant proteins A and D, complement factor C1q, lactoferrin and albumin [16-18,21,25,89,108,109]. $\mathrm{DMBT} 11^{\mathrm{SAG}}$ binds to secretory $\operatorname{IgA}$ in a calcium-dependent manner, resulting in a cooperative effect on bacterial aggregation $[15,110]$. Binding of $\mathrm{DMBT} 1^{\mathrm{SAG}}$ to $\mathrm{IgA}$ is mediated by the same 11 -mer peptide that is responsible for the broad-spectrum bacteria binding of DMBT1 ${ }^{\mathrm{SAG}}$ [18]. Binding of a DMBT1 $1^{\text {SAG }}$-IgA complex to the Pac molecule of $S$. mutans was demonstrated [52]. After chemical reduction, this complex was dissociated into $\operatorname{SIgA}$ and DMBT1 ${ }^{\text {SAG }}$ and concomitantly binding to Pac disappeared.

DMBT $^{\text {SAG }}$ also binds to C1q of the complement system, a system of plasma proteins that may react with one another to opsonize or permeabilize pathogens and induce a series of inflammatory responses [109]. By binding of SAG to C1q, the complement system is activated through the classical pathway [16]. Although DMBT1 ${ }^{\mathrm{SAG}}$ is secreted in saliva and $\mathrm{C} 1 \mathrm{q}$ is a serum component, these two fluids may mix in the oral cavity under conditions of oral inflammation, e.g., periodontal disease, or mucosal damage, thus enabling a local complement activation.

DMBT1 also binds to bovine and human lactoferrin, an $80 \mathrm{kDa}$ iron binding protein belonging to the transferrin family [17,19]. Lactoferrin exhibits various functions in the innate immune system. It sequesters iron from the local environment thus inhibiting microbial growth and it prevents the formation of Pseudomonas biofilms [111]. In addition, antimicrobial peptides are released upon proteolytic degradation of lactoferrin [112]. Bovine lactoferrin inhibits DMBT1 ${ }^{\text {SAG }}$ binding to S. mutans protein antigen Pac, which belongs to the antigen I/II family [17]. The SRCRP2 peptide of 
DMBT1 $1^{\text {SAG }}$ that is responsible for $S$. mutans binding also mediates binding of lactoferrin $[17,89]$. Bovine lactoferrin residues 480-492 (SCAFDEFFSQSCA) are important for DMBT1 ${ }^{\text {SAG }}$ binding. Although the homologous sequence in human lactoferrin is slightly different (SCKFDEYFSQSCA), human lactoferrin also binds to DMBT1 [19].

DMBT $1^{\mathrm{GP} 340}$, which originally was isolated as a soluble receptor for SP-D, also binds SP-A [20,25]. SP-A and SP-D are collagen-containing (C-type) calcium-dependent lectins called collectins [113]. SP-D forms oligomers of 4-8 subunits. Each subunit is composed of three identical polypeptides of $43 \mathrm{kDa}$ held together by disulfide bonds and non-covalent interactions at the $N$-terminal ends of the chains. Each polypeptide consists of a short $N$-terminal region, followed by a collagen-like sequence, a short $\alpha$-helical sequence and the carbohydrate recognition domain. DMBT $1^{\text {GP340 }}$ binds to the carbohydrate recognition domain of SP-D through a calcium-dependent protein-protein interaction [20]. SP-A and SP-D are involved in a range of immune functions including viral neutralization, aggregation and killing of bacteria and fungi, and clearance of apoptotic and necrotic cells.

\section{Role of DMBT1 in Innate Immunity}

Due to their broad pathogen binding spectrum, DMBT1 and its mouse homolog CRP-ductin are considered pattern recognition receptors (PRRs) [101], an ancient germline encoded defense system against pathogen invasion in both plants and animals [114,115]. PRRs recognize conserved structures of the microbial cell that are vital for survival, so-called pathogen-associated molecular patterns (PAMPs). PAMPs include mannans and zymosan of the yeast cell wall, various bacterial cell-wall components, such as lipoteichoic acid (LTA) of Gram-positive bacteria or lipopolysaccharide (LPS) of Gram-negative bacteria, and bacterial DNA [116,117]. In the human body, PRRs are found on host-pathogen interacting surfaces and expressed by epithelial cells, macrophages, granulocytes and dendritic cells or as secretory products present in mucosal fluids [115,118]. These characteristics are also applicable to DMBT1. PRRs form a diverse group of proteins including mannose-binding lectin, collectins, CD14, Toll-like receptors and Nucleotide-binding oligomerization domain (Nod) proteins $[70,115,119,120]$. The SRCR proteins SR-AI and SR-AII, MARCO and Spa, also belong to this group.

\section{Conclusions}

Conclusively, DMBT1 plays a role in innate immunity by binding to a large panel of exogenous and endogenous ligands. SRCRP2 on the SRCR domains and sialic acids on the glycan chains have been identified as ligand binding sites, but DMBT1 may harbor many other potential ligand binding sites. These many ligand binding sites and its structural heterogeneity - both in the different tissues and between different individuals - are only two of the many surprises hidden in this molecule. Future research should focus on the precise role of DMBT1 in the innate immune system and the physiological consequences of its heterogeneity. 


\section{References}

1. Tlaskalova-Hogenova, H.; Tuckova, L.; Mestecky, J.; Kolinska, J.; Rossmann, P.; Stepankova, R.; Kozakova, H.; Hudcovic, T.; Hrncir, T.; Frolova, L.; Kverka, M. Interaction of mucosal microbiota with the innate immune system. Scand. J. Immunol. 2005, 62, 106-113.

2. Schenkels, L.C.P.M.; Veerman, E.C.I.; Nieuw Amerongen, A.V. Biochemical composition of human saliva in relation to other mucosal fluids. Crit. Rev. Oral Biol. Med. 1995, 6, 161-175.

3. Valdez, I.H.; Fox, P.C. Diagnosis and management of salivary dysfunction. Critical Reviews in Oral Biol. Med. 1993, 4, 271-277.

4. Daniels, T.E. Evaluation, differential diagnosis, and treatment of xerostomia. J. Rheumatol. 2000, 27, 6-10.

5. Almstahl, A.; Wikstrom, M.; Stenberg, I.; Jakobsson, A.; Fagerberg-Mohlin, B. Oral microbiota associated with hyposalivation of different origins. Oral Microbiol. Immunol. 2003, 18, 1-8.

6. Scannapieco, F.A. Role of oral bacteria in respiratory infection. J. Periodontol. 1999, 70, 793-802.

7. Kolenbrander, P.E.; London, J. Adhere today, here tomorrow: Oral bacterial adherence. $J$. Bacteriol. 1993, 175, 3247-3252.

8. Gibbons, R.J. Adherent interactions which may affect microbial ecology in the mouth. J. Dent. Res. 1984, 63, 378-385.

9. Emilson, C.G.; Ciardi, J.E.; Olsson, J.; Bowen, W.H. The influence of saliva on infection of the human mouth by mutans streptococci. Arch. Oral Biol. 1989, 34, 335-340.

10. Rudney, J.D.; Pan, Y.; Chen, R. Streptococcal diversity in oral biofilms with respect to salivary function. Arch. Oral Biol. 2003, 48, 475-493.

11. Rudney, J.D. Does variability in salivary protein concentrations influence oral microbial ecology and oral health? Crit. Rev. Oral Biol. Med. 1995, 6, 343-367.

12. Ericson, T.; Rundegren, J. Characterization of a salivary agglutinin reacting with a serotype c strain of Streptococcus mutans. Eur. J. Biochem. 1983, 133, 255-261.

13. Ligtenberg, A.J.; Veerman, E.C.; Nieuw Amerongen, A.V. A role for Lewis a antigens on salivary agglutinin in binding to Streptococcus mutans. Antonie van Leeuwenhoek 2000, 77, 21-30.

14. Rundegren, J. Calcium-dependent salivary agglutinin with reactivity to various oral bacterial species. Infect. Immun. 1986, 53, 173-178.

15. Rundegren, J.; Arnold, R.R. Differentiation and interaction of secretory immunoglobulin A and a calcium-dependent parotid agglutinin for several bacterial strains. Infect. Immun. 1987, 55, 288-292.

16. Boackle, R.J.; Connor, M.H.; Vesely, J. High molecular weight non-immunoglobulin salivary agglutinins (NIA) bind C1Q globular heads and have the potential to activate the first complement component. Mol. Immunol. 1993, 30, 309-319.

17. Mitoma, M.; Oho, T.; Shimazaki, Y.; Koga, T. Inhibitory effect of bovine milk lactoferrin on the interaction between a streptococcal surface protein antigen and human salivary agglutinin. $J$. Biol. Chem. 2001, 276, 18060-18065.

18. Ligtenberg, A.J.M.; Bikker, F.J.; de Blieck-Hogervorst, J.M.A.; Veerman, E.C.I.; Nieuw Amerongen, A.V. Binding of salivary agglutinin to IgA. Biochem. J. 2004, 383, 159-164.

19. End, C.; Lyer, S.; Renner, M.; Stahl, C.; Ditzer, J.; Holloschi, A.; Kuhn, H.M.; Flammann, H.T.; Poustka, A.; Hafner, M.; Mollenhauer, J.; Kioschis, P. Generation of a vector system facilitating 
cloning of DMBT1 variants and recombinant expression of functional full-length DMBT1. Protein Expres. Purif. 2005, 41, 275-286.

20. Holmskov, U.; Lawson, P.; Teisner, B.; Tornoe, I.; Willis, A.C.; Morgan, C.; Koch, C.; Reid, K.B.M. Isolation and characterization of a new member of the Scavenger receptor superfamily, glycoprotein-340 (GP340), as a lung surfactant protein D binding molecule. J. Biol. Chem. 1997, $272,13743-13749$.

21. Ligtenberg, T.J.M.; Bikker, F.J.; Groenink, J.; Tornoe, I.; Leth-Larsen, R.; Veerman, E.C.I.; Amerongen, A.V.N.; Holmskov, U. Human salivary agglutinin binds to lung surfactant protein$\mathrm{D}$ and is identical with scavenger receptor protein gp-340. Biochem. J. 2001, 359, 243-248.

22. Prakobphol, A.; Xu, F.; Hoang, V.M.; Larsson, T.; Bergstrom, J.; Johansson, I.; Frangsmyr, L.; Holmskov, U.; Leffler, H.; Nilsson, C.; Boren, T.; Wright, J.R.; Stromberg, N.; Fisher, S.J. Salivary agglutinin, which binds Streptococcus mutans and Helicobacter pylori, is the lung scavenger receptor cysteine-rich protein gp-340. J. Biol. Chem. 2000, 275, 39860-39866.

23. Holmskov, U.; Mollenhauer, J.; Madsen, J.; Vitved, L.; Gronlund, J.; Tornoe, I.; Kliem, A.; Reid, K.B.M.; Poustka, A.; Skjodt, K. Cloning of GP-340, a putative opsonin receptor for lung surfactant protein D. Proc. Natl. Acad. Sci. USA 1999, 96, 10794-10799.

24. Mollenhauer, J.; Wiemann, S.; Scheurlen, W.; Korn, B.; Hayashi, Y.; Wilgenbus, K.K.; vonDeimling, A.; Poustka, A. DMBT1, a new member of the SRCR superfamily, on chromosome 10q25.3-26.1 is deleted in malignant brain tumours. Nat. Genet. 1997, 17, 32-39.

25. Tino, M.J.; Wright, J.R. Glycoprotein-340 binds surfactant protein-A (SP-A) and stimulates alveolar macrophage migration in an SP-A-independent manner. Am. J. Respirat. Cell Mol. Biol. 1999, 20, 759-768.

26. Crouch, E.; Hartshorn, K.; Ofek, I. Collectins and pulmonary innate immunity. Immunol. Rev. 2000, 173, 52-65.

27. Mori, M.; Shiraishi, T.; Tanaka, S.; Yamagata, M.; Mafune, K.; Tanaka, Y.; Ueo, H.; Barnard, G.F.; Sugimachi, K. Lack of DMBT1 expression in oesophageal, gastric and colon cancers. $B r$. J. Cancer 1999, 79, 211-213.

28. Somerville, R.P.T.; Shoshan, Y.; Eng, C.; Barnett, G.; Miller, D.; Cowell, J.K. Molecular analysis of two putative tumour suppressor genes, PTEN and DMBT, which have been implicated in glioblastoma multiforme disease progression. Oncogene 1998, 17, 1755-1757.

29. Wu, W.G.; Kemp, B.L.; Proctor, M.L.; Gazdar, A.F.; Minna, J.D.; Hong, W.K.; Mao, L. Expression of DMBT1, a candidate tumor suppressor gene, is frequently lost in lung cancer. Cancer Res. 1999, 59, 1846-1851.

30. Mollenhauer, J.; Holmskov, U.; Wiemann, S.; Krebs, I.; Herbertz, S.; Madsen, J.; Kioschis, P.; Coy, J.F.; Poustka, A. The genomic structure of the DMBT1 gene: Evidence for a region with susceptibility to genomic instability. Oncogene 1999, 18, 6233-6240.

31. Braidotti, P.; Nuciforo, P.G.; Mollenhauer, J.; Poustka, A.; Pellegrini, C.; Moro, A.; Bulfamante, G.; Coggi, G.; Bosari, S.; Pietra, G.G. DMBT1 expression is down-regulated in breast cancer. Bmc Cancer 2004, 4.

32. Mollenhauer, J.; Muller, H.; Kollender, G.; Lyer, S.; Diedrichs, L.; Helmke, B.; Holmskov, U.; Ligtenberg, T.; Herbertz, S.; Krebs, I.; Madsen, J.; Bikker, F.; Schmitt, L.; Wiemann, S.; Scheurlen, W.; Otto, H.F.; von Deimling, A.; Poustka, A. The SRCR/SID region of DMBT1 
defines a complex multi-allele system representing the major basis for its variability in cancer. Genes Chromosomes Cancer 2002, 35, 242-255.

33. Mollenhauer, J.; Helmke, B.; Muller, H.; Kollender, G.; Lyer, S.; Diedrichs, L.; Holmskov, U.; Ligtenberg, T.; Herbertz, S.; Krebs, I.; Wiemann, S.; Madsen, J.; Bikker, F.; Schmitt, L.; Otto, H.F.; Poustka, A. Sequential changes of the DMBT1 expression and location in normal lung tissue and lung carcinomas. Genes Chromosomes Cancer 2002, 35, 164-169.

34. Mollenhauer, J.; Deichmann, M.; Helmke, B.; Muller, H.; Kollender, G.; Holmskov, U.; Ligtenberg, T.; Krebs, I.; Wiemann, S.; Bantel-Schaal, U.; Madsen, J.; Bikker, F.; Klauck, S.M.; Otto, H.F.; Moldenhauer, G.; Poustka, A. Frequent downregulation of DMBT1 and galectin-3 in epithelial skin cancer. Int. J. Cancer 2003, 105, 149-157.

35. Mollenhauer, J.; Herbertz, S.; Helmke, B.; Kollender, G.; Krebs, I.; Madsen, J.; Holmskov, U.; Sorger, K.; Schmitt, L.; Wiemann, S.; Otto, H.F.; Grone, H.J.; Poustka, A. Deleted in Malignant Brain Tumors 1 is a versatile mucin-like molecule likely to play a differential role in digestive tract cancer. Cancer Res. 2001, 61, 8880-8886.

36. Mollenhauer, J.; Helmke, B.; Medina, D.; Bergmann, G.; Gassler, N.; Muller, H.; Lyer, S.; Diedrichs, L.; Renner, M.; Wittig, R.; Blaich, S.; Hamann, U.; Madsen, J.; Holmskov, U.; Bikker, F.; Ligtenberg, A.; Carlen, A.; Olsson, J.; Otto, H.F.; O'Malley, B.; Poustka, A. Carcinogen inducibility in vivo and down-regulation of DMBTI during breast carcinogenesis. Genes Chromosomes Cancer 2004, 39, 185-194.

37. Aruffo, A.; Bowen, M.A.; Patel, D.D.; Haynes, B.F.; Starling, G.C.; Gebe, J.A.; Bajorath, J. CD6-ligand interactions: A paradigm for SRCR domain function? Immunol. Today 1997, 18, 498-504.

38. Resnick, D.; Pearson, A.; Krieger, M. The SRCR superfamily: A family reminiscent of the Ig superfamily. Trends Biochem. Sci. 1994, 19, 5-8.

39. Bork, P.; Beckmann, G. The CUB Domain - a widespread module in developmentally-regulated proteins. J. Mol. Biol. 1993, 231, 539-545.

40. Sarrias, M.R.; Gronlund, J.; Padilla, O.; Madsen, J.; Holmskov, U.; Lozano, F. The scavenger receptor cysteine-rich (SRCR) domain: An ancient and highly conserved protein module of the innate immune system. Crit. Rev. Immunol. 2004, 24, 1-37.

41. Muller, W.E.G. Origin of metazoan adhesion molecules and adhesion receptors as deduced from cDNA analysis in the marine sponge Geodia cydonium: A review. Cell Tissue Res. 2003, 289, 383-395.

42. Hohenester, E.; Sasaki, T.; Timpl, R. Crystal structure of a scavenger receptor cysteine-rich domain sheds light on an ancient superfamily. Nat. Struct. Biol. 1999, 6, 228-232.

43. Claudianos, C.; Dessens, J.T.; Trueman, H.E.; Arai, M.; Mendoza, J.; Butcher, G.A.; Crompton, T.; Sinden, R.E. A malaria scavenger receptor-like protein essential for parasite development. Mol. Microbiol. 2002, 45, 1473-1484.

44. Abrahamsen, M.S.; Templeton, T.J.; Enomoto, S.; Abrahante, J.E.; Zhu, G.; Lancto, C.A.; Deng, M.Q.; Liu, C.; Widmer, G.; Tzipori, S.; Buck, G.A.; Xu, P.; Bankier, A.T.; Dear, P.H.; Konfortov, B.A.; Spriggs, H.F.; Iyer, L.; Anantharaman, V.; Aravind, L.; Kapur, V. Complete genome sequence of the apicomplexan, Cryptosporidium parvum. Science 2004, 304, 441-445. 
45. Rast, J.P.; Smith, L.C.; Loza-Coll, M.; Hibino, T.; Litman, G.W. Genomic insights into the immune system of the sea urchin. Science 2006, 314, 952-956.

46. Romero, A.; Romao, M.J.; Varela, P.F.; Kolln, I.; Dias, J.; Carvalho, A.L.; Sanz, L.; TopferPetersen, E.; Calvette, J.J. The crystal structures of two spermadhesins reveal the CUB domain fold. Nat. Struct. Biol. 1997, 4, 783-788.

47. Bork, P.; Sander, C. A large domain common to sperm receptors (ZP2 and ZP3) and TGF-beta type-III receptor. Febs Lett. 1992, 300, 237-240.

48. Jovine, L.; Qi, H.Y.; Williams, Z.; Litscher, E.S.; Wassarman, P.M. A duplicated motif controls assembly of zona pellucida domain proteins. Proc. Natl. Acad. Sci. USA 2004, 101, 5922-5927.

49. Jovine, L.; Qi, H.Y.; Williams, Z.; Litscher, E.; Wassarman, P.M. The ZP domain is a conserved module for polymerization of extracellular proteins. Nat. Cell Biol. 2002, 4, 457-461.

50. Jovine, L.; Darie, C.C.; Litscher, E.S.; Wassarman, P.M. Zona pellucida domain proteins. Annu. Rev. Biochem. 2005, 74, 83-114.

51. Young, A.; Rykke, M.; Smistad, G.; Rolla, G. On the role of human salivary micelle-like globules in bacterial agglutination. Eur. J. Oral Sci. 1997, 105, 485-494.

52. Oho, T.; Yu, H.; Yamashita, Y.; Koga, T. Binding of salivary glycoprotein-secretory immunoglobulin a complex to the surface protein antigen of Streptococcus mutans. Infect. Immun. 1998, 66, 115-121.

53. Rose, M.C.; Voter, W.A.; Sage, H.; Brown, C.F.; Kaufman, B. Effects of deglycosylation on the architecture of ovine submaxillary mucin glycoprotein. J. Biol. Chem. 1984, 259, 3167-3172.

54. Amado, M.; Almeida, R.; Schwientek, T.; Clausen, H. Identification and characterization of large galactosyltransferase gene families: Galactosyltransferases for all functions. Biochim. Biophys. Acta-Gen. Subjects 1999, 1473, 35-53.

55. Eriksson, C.; Frangsmyr, L.; Niemi, L.D.; Loimaranta, V.; Holmskov, U.; Bergman, T.; Leffler, H.; Jenkinson, H.F.; Stromberg, N. Variant size- and glycoforms of the scavenger receptor cysteine-rich protein gp-340 with differential bacterial aggregation. Glycoconj. J. 2007, 24, 131-142.

56. Ciopraga, J.; Motas, C.; Doyle, R.J. Inhibition of saliva-induced oral streptococcal aggregation by blood-group glycoproteins. Fems Immun. Med. Microbiol. 1995, 10, 145-149.

57. Ligtenberg, A.J.M.; Veerman, E.C.I.; de Graaff, J.; Nieuw Amerongen, A.V. Influence of the blood-group reactive substances in saliva on the aggregation of Streptococcus rattus. Antonie Van Leeuwenhoek 1990, 57, 97-107.

58. Ligtenberg, A.J.M.; Veerman, E.C.I.; de Graaff, J.; Nieuw Amerongen, A.V. Saliva-induced aggregation of oral streptococci and the influence of blood-group reactive substances. Arch. Oral Biol. 1990, 35, S141-S143.

59. Arneberg, P.; Kornstad, L.; Nordbo, H.; Gjermo, P. Less dental-caries among secretors than among non-secretors of blood-group substance. Scand. J. Dent. Res. 1976, 84, 362-366.

60. Hartshorn, K.L.; Ligtenberg, A.; White, M.R.; van Eijk, M.; Hartshorn, M.; Pemberton, L.; Holmskov, U.; Crouch, E. Salivary agglutinin and lung scavenger receptor cysteine-rich glycoprotein 340 have broad anti-influenza activities and interactions with surfactant protein D that vary according to donor source and sialylation. Biochem. J. 2006, 393, 545-553. 
61. Schulz, B.L.; Oxley, D.; Packer, N.H.; Karlsson, N.G. Identification of two highly sialylated human tear-fluid DMBT1 isoforms: The major high-molecular-mass glycoproteins in human tears. Biochem. J. 2002, 366, 511-520.

62. Yeh, J.C.; Hiraoka, N.; Petryniak, B.; Nakayama, J.; Ellies, L.G.; Rabuka, D.; Hindsgaul, O.; Marth, J.D.; Lowe, J.B.; Fukuda, M. Novel sulfated lymphocyte homing receptors and their control by a core1 extension beta 1, 3-N-acetylglucosaminyltransferase. Cell 2001, 105, 957-969.

63. Prakobphol, A.; Boren, T.; Ma, W.; Peng, Z.X.; Fisher, S.J. Highly glycosylated human salivary molecules present oligosaccharides that mediate adhesion of leukocytes and Helicobacter pylori. Biochemistry 2005, 44, 2216-2224.

64. Issa, S.; Moran, A.P.; Ustinov, S.N.; Lin, J.H.; Ligtenberg, A.J.; Karlsson, N.G. O-linked oligosaccharides from salivary agglutinin: Helicobacter pylori binding sialyl-Lewis $\mathrm{x}$ and Lewis b are terminating moieties on hyperfucosylated oligo-N-acetyllactosamine. Glycobiology 2010, 20, 1046-1057.

65. Bikker, F.J.; Ligtenberg, A.J.; Nazmi, K.; Veerman, E.C.; van't Hof, W.; Bolscher, J.G.; Poustka, A.; Nieuw Amerongen, A.V.; Mollenhauer, J. Identification of the bacteria-binding peptide domain on salivary agglutinin (gp-340/DMBT1), a member of the scavenger receptor cysteinerich superfamily. J. Biol. Chem. 2002, 277, 32109-32115.

66. Bikker, F.J.; Ligtenberg, A.J.M.; End, C.; Renner, M.; Blaich, S.; Lyer, S.; Wittig, R.; van't Hof, W.; Veerman, E.C.I.; Nazmi, K.; de Blieck-Hogervorst, J.M.A.; Kioschis, P.; Nieuw Amerongen, A.V.; Poustka, A.; Mollenhauer, J. Bacteria binding by DMBT1/SAG/gp-340 is confined to the VEVLXXXXW motif in its scavenger receptor cysteine-rich domains. J. Biol. Chem. 2004, 279, 47699-47703.

67. Leito, J.T.D.; Ligtenberg, A.J.M.; Nazmi, K.; de Blieck-Hogervorst, J.M.A.; Veerman, E.C.I.; Nieuw Amerongen, A.V. A common binding motif for various bacteria of the bacteria-binding peptide SRCRP2 of DMBT1/gp-340/salivary agglutinin. Biol. Chem. 2008, 389, 1193-1200.

68. Elomaa, O.; Kangas, M.; Sahlberg, C.; Tuukkanen, J.; Sormunen, R.; Liakka, A.; Thesleff, I.; Kraal, G.; Tryggvason, K. Cloning of a novel bacteria-binding receptor structurally related to scavenger receptors and expressed in a subset of macrophages. Cell 1995, 80, 603-609.

69. Elomaa, O.; Sankala, M.; Pikkarainen, T.; Bergmann, U.; Tuuttila, A.; Raatikainen-Ahokas, A.; Sariola, H.; Tryggvason, K. Structure of the human macrophage MARCO receptor and characterization of its bacteria-binding region. J. Biol. Chem. 1998, 273, 4530-4538.

70. Kraal, G.; van der Laan, L.J.; Elomaa, O.; Tryggvason, K. The macrophage receptor MARCO. Microb. Infect. 2000, 2, 313-316.

71. Brannstrom, A.; Sankala, M.; Tryggvason, K.; Pikkarainen, T. Arginine residues in domain V have a central role for bacteria-binding activity of macrophage scavenger receptor MARCO. Biochem. Biophys. Res. Commun. 2002, 290, 1462-1469.

72. Sankala, M.; Brannstrom, A.; Schulthess, T.; Bergmann, U.; Morgunova, E.; Engel, J.; Tryggvason, K.; Pikkarainen, T. Characterization of recombinant soluble macrophage scavenger receptor MARCO. J. Biol. Chem. 2002, 277, 33378-33385. 
73. Sarrias, M.R.; Rosello, S.; Sanchez-Barbero, F.; Sierra, J.M.; Vila, J.; Yelamos, J.; Vives, J.; Casals, C.; Lozano, F. A role for human SP alpha as a pattern recognition receptor. J. Biol. Chem. 2005, 280, 35391-35398.

74. Sarrias, M.R.; Farnos, M.; Mota, R.; Sanchez-Barbero, F.; Ibanez, A.; Gimferrer, I.; Vera, J.; Fenutria, R.; Casals, C.; Yelamos, J.; Lozano, F. CD6 binds to pathogen-associated molecular patterns and protects from LPS-induced septic shock. Proc. Natl. Acad. Sci. USA 2007, 104, 11724-11729.

75. Fabriek, B.O.; van, B.R.; Deng, D.M.; Ligtenberg, A.J.; Nazmi, K.; Schornagel, K.; Vloet, R.P.; Dijkstra, C.D.; van den Berg, T.K. The macrophage scavenger receptor CD163 functions as an innate immune sensor for bacteria. Blood 2009, 113, 887-892.

76. Schengrund, C.L. "Multivalent" saccharides: Development of new approaches for inhibiting the effects of glycosphingolipid-binding pathogens. Biochem. Pharmacol. 2003, 65, 699-707.

77. Boren, T.; Falk, P. Helicobacter pylori binds to blood group antigens. Scientific Am. 1994, $28-37$.

78. Demuth, D.R.; Lammey, M.S.; Huck, M.; Lally, E.T.; Malamud, D. Comparison of Streptococcus mutans and Streptococcus sanguis receptors for human salivary agglutinin. Microb. Pathogenesis 1990, 9, 199-211.

79. Stenudd, C.; Nordlund, A.; Ryberg, M.; Johansson, I.; Kallestal, C.; Stromberg, N. The association of bacterial adhesion with dental caries. J. Dent. Res. 2001, 80, 2005-2010.

80. Carlen, A.; Bratt, P.; Stenudd, C.; Olsson, J.; Stromberg, N. Agglutinin and acidic proline-rich protein receptor patterns may modulate bacterial adherence and colonization on tooth surfaces. $J$. Dent. Res. 1998, 77, 81-90.

81. Rosan, B.; Appelbaum, B.; Golub, E.; Malamud, D.; Mandel, I.D. Enhanced saliva-mediated bacterial aggregation and decreased bacterial adhesion in caries-resistant versus cariessusceptible individuals. Infect. Immun. 1982, 38, 1056-1059.

82. Jenkinson, H.F.; Demuth, D.R. Structure, function and immunogenicity of streptococcal antigen I/II polypeptides [review]. Mol. Microbiol. 1997, 23, 183-190.

83. brady, L.J.; Maddocks, S.E.; Larson, M.R.; Forsgren, N.; Persson, K.; Deivanayagam, C.C.; Jenkinson, H.F. The changing faces of Streptococcus antigen I/II polypeptide family adhesins. Mol. Microbiol. 2010, 77, 276-286.

84. Kelly, C.G.; Todryk, S.; Kendal, H.L.; Munro, G.H.; Lehner, T. T-cell, adhesion, and B-cell epitopes of the cell surface Streptococcus mutans protein antigen I/II. Infect. Immun. 1995, 63, 3649-3658.

85. Kelly, C.G.; Younson, J.S.; Hikmat, B.Y.; Todryk, S.M.; Czisch, M.; Haris, P.I.; Flindall, I.R.; Newby, C.; Mallet, A.I.; Ma, J.K.; Lehner, T. A synthetic peptide adhesion epitope as a novel antimicrobial agent. Nat. Biotechnol. 1999, 17, 42-47.

86. Jakubovics, N.S.; Stromberg, N.; van Dolleweerd, C.J.; Kelly, C.G.; Jenkinson, H.F. Differential binding specificities of oral streptococcal antigen I/II family adhesins for human or bacterial ligands. Mol. Microbiol. 2005, 55, 1591-1605.

87. Hamada, T.; Kawashima, M.; Watanabe, H.; Tagami, J.; Senpuku, H. Molecular interactions of surface protein peptides of Streptococcus gordonii with human salivary components. Infect. Immun. 2004, 72, 4819-4826. 
88. Koba, H.; Okuda, K.; Watanabe, H.; Tagami, J.; Senpuku, H. Role of lysine in interaction between surface protein peptides of Streptococcus gordonii and agglutinin peptide. Oral Microbiol. Immunol. 2009, 24, 162-169.

89. Oho, T.; Bikker, F.J.; Nieuw Amerongen, A.V.; Groenink, J. A peptide domain of bovine milk lactoferrin inhibits the interaction between streptococcal surface protein antigen and a salivary agglutinin peptide domain. Infect. Immun. 2004, 72, 6181-6184.

90. Niemi, L.D.; Johansson, I. Salivary statherin peptide-binding epitopes of commensal and potentially infectious Actinomyces spp. delineated by a hybrid peptide construct. Infect. Immun. 2004, 72, 782-787.

91. Niemi, L.D.; Hernell, O.; Johansson, I. Human milk compounds inhibiting adhesion of mutans streptococci to host ligand-coated hydroxyapatite in vitro. Caries Res. 2009, 43, 171-178.

92. Wu, Z.W.; Golub, E.; Abrams, W.R.; Malamud, D. gp340 (SAG) binds to the V3 sequence of gp120 important for chemokine receptor interaction. Aids Res. Hum. Retroviruses 2004, 20, 600-607.

93. Larson, M.R.; Rajashankar, K.R.; Patel, M.H.; Robinette, R.A.; Crowley, P.J.; Michalek, S.; Brady, L.J.; Deivanayagam, C. Elongated fibrillar structure of a streptococcal adhesin assembled by the high-affinity association of alpha- and PPII-helices. Proc. Natl. Acad. Sci. USA 2010, 107, 5983-5988.

94. Troffer-Charlier, N.; Ogier, J.; Moras, D.; Cavarelli, J. Crystal structure of the V-region of Streptococcus mutans antigen I/II at 2.4 angstrom resolution suggests a sugar preformed binding site. J. Mol. Biol. 2002, 318, 179-188.

95. Loimaranta, V.; Jakubovics, N.S.; Hytonen, J.; Finne, J.; Jenkinson, H.F.; Stromberg, N. Fluidor surface-phase human salivary scavenger protein gp340 exposes different bacterial recognition properties. Infect. Immun. 2005, 73, 2245-2252.

96. Brady, L.J.; Piacentini, D.A.; Crowley, P.J.; Oyston, P.C.F.; Bleiweis, A.S. Differentiation of salivary agglutinin-mediated adherence and aggregation of mutans streptococci by use of monoclonal-antibodies against the major surface adhesin-P1. Infect. Immun. 1992, 60, 1008-1017.

97. Zhang, Y.; Lei, Y.; Nobbs, A.; Khammanivong, A.; Herzberg, M.C. Inactivation of Streptococcus gordonii SspAB alters expression of multiple adhesin genes. Infect. Immun. 2005, 73, 3351-3357.

98. Gibbons, R.J.; Hay, D.I.; Childs, W.C.; Davis, G. Role of cryptic receptors (cryptitopes) in bacterial adhesion to oral-surfaces. Arch. Oral Biol. 1990, 35, S107-S114.

99. Gibbons, R.J.; Hay, D.I. Human salivary acidic proline-rich proteins and statherin promote the attachment of Actinomyces viscosus LY7 to apatitic surfaces. Infect. Immun. 1988, 56, 439-445.

100. Goobes, G.; Goobes, R.; Schueler-Furman, O.; Baker, D.; Stayton, P.S.; Drobny, G.P. Folding of the C-terminal bacterial binding domain in statherin upon adsorption onto hydroxyapatite crystals. Proc. Natl. Acad. Sci. USA 2006, 103, 16083-16088.

101. Madsen, J.; Tornoe, I.; Nielsen, O.; Lausen, M.; Krebs, I.; Mollenhauer, J.; Kollender, G.; Poustka, A.; Skjodt, K.; Holmskov, U. CRP-ductin, the mouse homologue of gp-340/deleted in malignant brain tumors 1 (DMBT1), binds gram-positive and gram-negative bacteria and interacts with lung surfactant protein D. Eur. J. Immunol. 2003, 33, 2327-2336. 
102. End, C.; Bikker, F.; Renner, M.; Bergmann, G.; Lyer, S.; Blaich, S.; Hudler, M.; Helmke, B.; Gassler, N.; Autschbach, F.; Ligtenberg, A.J.; Benner, A.; Holmskov, U.; Schirmacher, P.; Nieuw Amerongen, A.V.; Rosenstiel, P.; Sina, C.; Franke, A.; Hafner, M.; Kioschis, P.; Schreiber, S.; Poustka, A.; Mollenhauer, J. DMBT1 functions as pattern-recognition molecule for poly-sulfated and poly-phosphorylated ligands. Eur. J. Immunol. 2009, 39, 833-842.

103. Wu, Z.; Van Ryk, D.; Davis, C.; Abrams, W.R.; Chaiken, I.; Magnani, J.; Malamud, D. Salivary agglutinin inhibits HIV type 1 infectivity through interaction with viral glycoprotein 120 . Aids Res. Hum. Retroviruses 2003, 19, 201-209.

104. Hartshorn, K.L.; White, M.R.; Mogues, T.; Ligtenberg, T.; Crouch, E.; Holmskov, U. Lung and salivary scavenger receptor glycoprotein-340 contribute to the host defense against influenza A viruses. Am. J. Physiol.-Lung Cell. Mol. Physiol. 2003, 285, L1066-L1076.

105. Sattentau, Q.J.; Moore, J.P. Conformational changes induced in the human-immunodeficiencyvirus envelope glycoprotein by soluble CD4 binding. J. Exp. Med. 1991, 174, 407-415.

106. Trkola, A.; Dragic, T.; Arthos, J.; Binley, J.M.; Olson, W.C.; Allaway, G.P.; ChengMayer, C.; Robinson, J.; Maddon, P.J.; Moore, J.P. CD4-dependent, antibody-sensitive interactions between HIV-1 and its co-receptor CCR-5. Nature 1996, 384, 184-187.

107. Wu, Z.W.; Lee, S.; Abrams, W.; Weissman, D.; Malamud, D. The N-terminal SRCR-SID domain of gp-340 interacts with HIV type 1 gp120 sequences and inhibits viral infection. Aids Res. Hum. Retroviruses 2006, 22, 508-515.

108. Thornton, D.J.; Davies, J.R.; Kirkham, S.; Gautrey, A.; Khan, N.; Richardson, P.S.; Sheehan, J.K. Identification of a nonmucin glycoprotein (gp-340) from a purified respiratory mucin preparation: Evidence for an association involving the MUC5B mucin. Glycobiology 2001, 11, 969-977.

109. Kojouharova, M.S.; Tsacheva, I.G.; Tchorbadjieva, M.I.; Reid, K.B.M.; Kishore, U. Localization of ligand-binding sites on human $\mathrm{C} 1 \mathrm{q}$ globular head region using recombinant globular head fragments and single-chain antibodies. Biochim. Biophys. Acta-Proteins Proteomics 2003, 1652, 64-74.

110. Armstrong, E.A.; Ziola, B.; Habbick, B.F.; Komiyama, K. Role of cations and IgA in salivamediated aggregation of Pseudomonas aeruginosa in cystic-fibrosis patients. J. Oral Pathol. Med. 1993, 22, 207-213.

111. Singh, P.K.; Parsek, M.R.; Greenberg, E.P.; Welsh, M.J. A component of innate immunity prevents bacterial biofilm development. Nature 2002, 417, 552-555.

112. Groenink, J.; Walgreen-Weterings, E.; van 't Hof, W.; Veerman, E.C.I.; Nieuw Amerongen, A.V. Cationic amphipatic peptides, derived from bovine and human lactoferrins, with antimicrobial activity against oral pathogens. FEMS Microbiol. Lett. 1999, 179, 217-222.

113. Kishore, U.; Greenhough, T.J.; Waters, P.; Shrive, A.K.; Ghai, R.; Kamran, M.F.; Bernal, A.L.; Reid, K.B.M.; Madan, T.; Chakraborty, T. Surfactant proteins SP-A and SP-D: Structure, function and receptors. Mol. Immunol. 2006, 43, 1293-1315.

114. Hoffmann, J.A.; Kafatos, F.C.; Janeway, C.A.; Ezekowitz, R.A. Phylogenetic perspectives in innate immunity. Science 1999, 1313-1318.

115. Janeway, C., Jr.; Medzhitov, R. Innate immune recognition. Annu. Rev. Immunol. 2003, 20, 197-216. 
116. Bainbridge, B.W.; Darveau, R.P. Porphyromonas gingivalis lipopolysaccharide: An unusual pattern recognition receptor ligand for the innate host defense system. Acta Odontol. Scand. 2001, 59, 131-138.

117. Ulevitch, R.J.; Mathison, J.C.; Correia, J.D. Innate immune responses during infection. Vaccine 2004, 22, S25-S30.

118. Medzhitov, R.; Janeway, C., Jr. Innate immunity. N. Engl. J. Med. 2000, 343, 338-343.

119. Aderem, A.; Ulevitch, R.J. Toll-like receptors in the induction of the innate immune response. Nature 2000, 406, 782-787.

120. Greaves, D.R.; Gordon, S. Recent insights into the biology of macrophage scavenger receptors. J. Lipid Res. 2005, 46, 11-20.

(C) 2010 by the authors; licensee MDPI, Basel, Switzerland. This article is an open access article distributed under the terms and conditions of the Creative Commons Attribution license (http://creativecommons.org/licenses/by/3.0/). 